NBER WORKING PAPER SERIES

\title{
INTERRACIAL CONTACT IN HIGH SCHOOL EXTRACURRICULAR ACTIVITIES
}

\author{
Charles T. Clotfelter \\ Working Paper 7999 \\ http://www.nber.org/papers/w7999 \\ NATIONAL BUREAU OF ECONOMIC RESEARCH \\ 1050 Massachusetts Avenue \\ Cambridge, MA 02138 \\ November 2000
}

I am grateful to Thomas Anderson, Chi Leng, Cathleen McHugh, Robert Malme, Karen Price, Martin Steinmeyer, and Jennifer Sturiale for research assistance, to Terri Finn for her assistance in making data available, to Philip Cook, Harriet Morgan, Theresa Newman, William Rodgers, and John Wilson for useful comments, and to Duke University for financial support. The views expressed in this paper are those of the author and not necessarily those of the National Bureau of Economic Research.

(C) 2000 by Charles T. Clotfelter. All rights reserved. Short sections of text, not to exceed two paragraphs, may be quoted without explicit permission provided that full credit, including (C) notice, is given to the source. 
Interracial Contact in High School Extracurricular Activities

Charles T. Clotfelter

NBER Working Paper No. 7999

November 2000

JEL No. 12

\begin{abstract}
Using data from yearbooks for 194 high schools, this study examines the degree of interracial contact in 8,875 high school teams and other organizations. Tabulations show that the degree of interracial exposure was typically less than what would occur if all organizations in each school had been racially balanced and was much less than the exposure that would have occurred if all organizations reflected the racial composition of the schools containing them. Whereas the nonwhite percentage of the students enrolled in the sample high schools was 25.1 percent, the membership of clubs and teams was 21.1 percent, reflecting a lower rate of participation by nonwhites. Furthermore, because the racial compositions of clubs and teams were not uniform, the average white member was in an organization that was only 15.6 percent nonwhite. Although clearly less than its theoretical maximum, this rate of contact nonetheless appears to be much higher than what would occur if friendships were the only vehicle for interracial contact outside the classroom. Finally, the extent of segregation associated with these organizations was the same or less in the South as compared to the rest of the country.
\end{abstract}

Charles T. Clotfelter

Box 90245

Duke University

Durham, NC 27708-0245

and NBER

Charles.Clotfelter@Duke.edu 
Contact among students of different racial and ethnic groups in schools remains an issue of profound social importance in this country. Despite the end of legal public school segregation in 1954 and the halting but nonetheless dramatic increases in school integration that occurred in the following two decades, the topic remains a concern of policymakers and continues to receive considerable attention from scholars. Employing enrollment data at the school level, numerous studies have documented the evolving patterns of interracial contact within public school districts. ${ }^{1}$ This research suggests that, while large disparities in racial composition exist among districts in many states and metropolitan areas, the schools within most districts are much more racially balanced. ${ }^{2}$ However, much less is known about interracial contact within schools. Casual observation of such features as segregated cafeterias and nearly all-white soccer or golf teams would suggest that there is less interracial contact within schools than school-wide enrollment figures would suggest, but there is little formal research to document those impressions. Such a divergence between school composition and actual contact could occur in three ways: if classes are not racially balanced (due to academic tracking, for example), if students select as friends other students in their own racial or ethnic groups, or if school sports teams or other extracurricular groups do not mirror a school's overall racial mix. 
The purpose of this paper is to examine the last of these three mechanisms, to document the extent of actual contact among students of different racial and ethnic groups in sports teams and other student organizations. What little research exists on the subject suggests that sports teams and other school organizations constitute significant terrain for the social adjustments to school desegregation, providing opportunities for both racial competition and acquaintance. ${ }^{3}$ Although it is not unambiguous, existing evidence appears to support the commonsensical proposition that more interracial contact is better than less, in the sense of undermining negative stereotypes and fostering positive racial attitudes. Contact can foster friendship, and friendships appear to be a key to positive effects over time. ${ }^{4}$ Thus the kind of informal contact provided by teams and other extracurricular organizations holds the promise for attitudes conducive to tolerance and cooperation among members of different racial groups. Interracial contact may also have an important role in integrating students into the social networks that play a large role in generating subsequent job opportunities. ${ }^{5}$

This paper uses data on the racial makeup of school groups gathered by examining a recent vintage of yearbooks for 194 public and private high schools. Information on participation and interracial exposure is calculated by school and type of organization. The paper is primarily descriptive in nature. It does not attempt to explore the causes of observed segregation. It seeks to measure neither the depth nor durability of the friendships that may arise from such contact. Nor does it assess other possible consequences of interracial contact, as important as those issues are. Instead, the aim of the paper is to document and measure the extent of interracial contact, a potentially important topic about which little empirical analysis has previously been undertaken. The first section of the paper provides some background on the historical and policy 
importance of this topic, the second section describes the data used, and the third presents the findings. There is a brief concluding section.

\section{Segregation, Desegregation, and the Role of Extracurricular Activities}

Few areas of social policy have experienced the kind of dramatic change that has occurred in the extent of interracial contact in the nation's public schools. One measure of the change wrought by school desegregation is the marked decline in the percentage of black students in the public schools who attended schools that were all- or virtually all-minority in racial composition. Between 1968 and 1988, the percentage of black students in the U.S. who attended public schools with minority enrollments between 90 to 100 percent dropped by half, from 64 to 32 percent. Among the nation's regions, this percentage declined the most in the South. In fact, by 1988 the South had the smallest percentage of black students attending such schools, 24 percent, while the Northeast had the highest, 48 percent (Orfield 1983, Table 2, p. 4 and Orfield and Monfort 1992, Table 8, p. 6). Although some slippage in interracial contact has occurred across the board, these regional patterns appear to have remained more or less constant into the 1990 s. $^{6}$

Despite these impressive changes, it is also apparent that several factors tend to limit the actual interracial contact within schools. One common feature of high schools that often appears to have this effect is academic tracking. Interracial contact is reduced if students of different racial groups are disproportionately assigned to some tracks, which has been one argument against its utilization. ${ }^{7}$ Whether such policies and practices are race-neutral or are motivated by pure racial prejudice, they have the effect of exacerbating segregation. Unfortunately, little is 
known about the quantitative effect of tracking on interracial contact, since relatively little information exists on racial contact within schools. Although data on the composition of classrooms within high schools was collected in the past, it is no longer. Using these older data, Morgan and McPartland (1981) examined patterns of interracial contact based on classroom assignments in public schools in the fall of 1976. They found a small degree of intra-school segregation, being more pronounced in high schools than in lower grades, greater in the South than elsewhere, and greatest in schools with approximately equal numbers of blacks and whites, as compared to those that were predominantly white or black. ${ }^{8}$ Because they represent a useful reference point, I return to these findings in the final section.

A second force acting within schools to reduce interracial contact is the general tendency toward self-segregation that can be observed in almost any social setting. Students, like most adults, tend to gravitate toward those similar to themselves. A striking illustration of this tendency in high schools is provided by a recent study of friendships. Using students' reports from the High School and Beyond sample on who their friends were, Hallinan and Williams (1989, p. 71) found that, out of some 18,000 friendship pairs studied, the proportion that involved students of different races was remarkably small, less than 2 percent.

A third factor influencing actual interracial contact is a largely overlooked vehicle for interaction: the teams, clubs, and other groups associated with extra-curricular activities. Belying their identification as "extra," extracurricular activities in fact play a rather important role in the high school experience. Over half of all high school students participate in athletic teams alone (McNeal 1998, p. 187). Developmentally, interracial contact in such organizations may have as much or more significance than that existing in classrooms. Granovetter (1986, p. 83) argues: 
In junior high and high school settings, extracurricular activities become a particular focus of out-of-class student interaction, and may take on greater significance for many students than the formal educational process.

Similarly, Hallinan and Williams (1989, p. 68) emphasize the importance of groups for fostering friendships among students:

Since interaction, whether by chance or by choice, generally leads to positive sentiment, students who are assigned or choose to belong to the same instructional groups or participate in joint co-curricular and extracurricular activities are more likely to become friends than those who are in different groups. ${ }^{9}$

One observable pattern of association relevant to interracial contact within schools is the racial mix of teams, clubs, and other groups associated with extra-curricular activities. As a vehicle for interracial contact, clubs and sports teams exist on a continuum somewhere between the externally imposed grouping of classroom assignments and the purely voluntary grouping created by friendships. Membership in some high school organizations - such as competitive sports teams and performing arts groups subject to tryouts - necessarily depends on skill and effort. Team membership may also be conditioned on grades and could as well, in some instances, be influenced by discriminatory practices of selection. By contrast, membership in many high school clubs is almost purely a matter of self-selection. Still other organizations, such as student government or academic honor societies, rely on voting and other formal selection procedures. ${ }^{10}$ In judging their importance for fostering interracial contact, however, the distinctions among these selection criteria seem less important than the resulting patterns of membership themselves.

The current paper utilizes published yearbooks to assess the degree of interracial contact in a sample of high schools. By focusing only on organizational membership, the paper does not 
attempt to distinguish the strength of friendship ties, the degree of reciprocity involved, or, indeed, the degree to which the patterns are voluntary. ${ }^{11}$

Among the questions that might be asked about contact in high school extracurricular activities, probably the most significant one is simply how much interracial contact exists. To measure this, the paper presents measures of racial composition and interracial exposure that have been commonly used in studies of racial segregation. Related questions of interest include: how interracial contact differs across regions, between public and private schools, and among types of organizations; how this contact compares to schools' overall racial composition; whether students of different racial and ethnic groups participate in extra-curricular activities at the same rates; how many students of another race a typical student associates with in organizations; and whether there exist racial compositions beyond which students are reluctant to participate in an organization. To address these questions, the paper turns to the data employed.

\section{Data and Measurement}

The principal data for the study are derived from a sample of 1997-98 high school yearbooks taken from a collection of sample copies produced by Jostens, Inc., a large yearbook publisher in Winston-Salem, NC. Limited only by the space available to transport them and the time required to examine them, research assistants took for study about 200 of these sample copies, making no effort to choose particular books or to balance the sample in any way. After eliminating yearbooks for elementary and middle schools, there remained 194 books for schools that covered high school grades. Because it was born of a unique opportunity to obtain a large number of books, and not from a random sample of all high schools, the sample, and the 
averages calculated from it, cannot be taken as representative of all American high schools. Most obviously, owing to the location of the publisher, the sample of schools covered is heavily weighted toward the South, East, and Midwest. The percentage of schools in the sample that are private is close to that of all high schools in the nation, but the average size of the sample schools is larger than average. ${ }^{12}$

Data for the study were obtained from a detailed examination of these yearbooks. For every sports team or other organization having a formal group picture in the yearbook, a count was made of the white, black, Hispanic, and other students. Ideally, the classification of students into racial and ethnic categories would be done by self-identification, the method used today in most social surveys and public documents, but that approach was obviously infeasible in this case. Thus classifications had to be based on visual inspection, using both facial appearance and names to indicate ethnicity. Still, the approach is not wholly satisfactory, both because it is subject to error and because it raises the thorny question of the very definition and validity of racial categories. Yet most people in contemporary America do commonly rely on such visual categorization. Although some ambiguity existed about the proper categories for a few of the faces pictured, readers generally had little difficulty classifying the vast majority of students pictured. In addition, efforts were made to insure that readers' judgements were reasonably consistent with each other. ${ }^{13}$ For the purposes of presentation, the organizations were grouped into athletic teams, performing arts groups, publications, and other organizations. Although the inclusion of pictures in a school's yearbook is typically the decision of one advisor and a group of students working under a constraints of time and money, making it unlikely that consistent criteria were followed for the inclusion of groups across these schools, there is no evidence of 
systematic bias regarding which organizations were included. No attempt was made to compile rosters of organizations or to record instances of multiple memberships.

Besides information on clubs and teams, it was important to know about each school's overall racial composition. For most of the public high schools in the sample, school racial composition was calculated from the Department of Education's Common Core of Data, a data set that covers public schools only. The most recent available data were for 1996-97, the year before that covered by the yearbooks. As a check on the comparability of those official data with estimates obtained from examining pictured students in yearbooks, comparisons were made for a random subsample of 10 high schools in the sample of 194 for total enrollment and racial mix. These comparisons showed that calculations based on the yearbooks understated total enrollment on average by only 2.5 percent and overstated the percentage of whites by less than 2 percentage points. For each of the private schools and a handful of brand-new public schools in the sample, for which there were no corresponding Common Core Data, overall racial composition was approximated by a count based on visual inspection of the yearbook using the same methods for counting described above. To keep this task manageable, the racial makeup of each these schools' $11^{\text {th }}$ grades was taken to be representative of the school at large. Total enrollment for each school was estimated to be four times the size of that junior class..$^{14}$

Table 1 presents a summary of the data collected for the 194 sample high schools, divided by region and type of school. Not surprisingly, the public schools on average had larger average enrollment, but the average number of organizations did not clearly differ by size of school. Among the public high schools, those in the South had much higher percentages of black students than those elsewhere, although other nonwhites were more common outside the South; 
these differences are very much in line with aggregate enrollment statistics for the nation. These differences are reversed among private schools, but the much smaller number of private schools may not yield representative racial compositions. Below the racial composition for schools is displayed the composition of school organizations. These data reveal that, on average, nonwhites participated proportionately less (based on numbers of members by race) than their white compatriots. For all the schools in the sample, the weighted average percentage nonwhite in organizations was 21.2 percent, somewhat less than the 25.1 percent share of nonwhites in total enrollment. $^{15}$

\section{Patterns of Interracial Contact in Clubs and Teams}

The degree of interracial contact in school organizations depends on three factors. First, the racial composition of school organizations is necessarily a function of that of the school from which they draw members. A school with no nonwhites can obviously have no nonwhites in its teams and clubs, so there obviously can be no interracial contact. Second, interracial contact depends on the degree to which students of different racial and ethnic groups participate in extracurricular activities. If students of any group join organizations at a lower than average rate, the potential for interracial contact is necessarily lessened. Using data from a national survey of high school students, McNeal (1998, p. 187) found that whites participated in most types of extracurricular activities at a higher rate than black or Hispanic students, the exceptions being cheerleading and vocational activities. The rate for Asian Americans exceeded that for whites in academic clubs, publications, and, to a small degree, in athletics. ${ }^{16}$ Table 1 reveals that, for the current sample, nonwhites comprise a smaller share of organizations than they do of school 
enrollment. This disparity could arise if a smaller percentage of nonwhites participated in extracurricular activities or if they joined fewer organizations on average than white students, or it could result from a combination of these two effects. Because the current data set does not allow the tracking of multiple memberships, it is impossible using it to distinguish between these two possible effects. Suffice it to say that the average rate of memberships per student is higher for white students than nonwhite students.

A third factor affecting interracial contact is the evenness with which students of the various groups are distributed across organizations. If a significant number of clubs or teams are composed entirely of students of one racial group, the potential for interracial contact obviously will be lessened. Indeed, an inspection of the sample of yearbooks reveals that such homogeneous groups are by no means uncommon. Out of the entire sample of 8,875 organizations in 194 schools, 3,130 (or 35.3 percent) were exclusively white and 253 (or 2.9 percent) were exclusively nonwhite. Even if one looks only at high schools with nonwhite enrollments between 10 and 90 percent (covering 102 schools), fully 19.1 percent of the organizations were all-white, and another 3.5 percent were exclusively nonwhite. To illustrate what kinds of organizations these were, Table 2 lists the all-white and all-nonwhite groups in 10 selected high schools in the sample. While some of the listed organizations -- especially clubs -appear to have race as an organizing principle, most do not. A listing of the homogeneous organizations in all 102 of the 10-to-90 percent nonwhite schools (not shown in the table) reveals that the most common all-white groups were golf, cheerleading, softball, and baseball. The allnonwhite groups appearing most often were boys' basketball, girls' track, black student union, ${ }^{17}$ and gospel choir. The larger list of homogeneous organizations confirms what is suggested in 
Table 2: a much higher proportion of all-nonwhite organizations were designed ostensibly for specific racial or ethnic groups. Of course, organizations need not be so thoroughly segregated for the degree of interracial contact to be affected. In general, the degree of segregation will depend on how the distribution of students across organizations differs from a racially balanced distribution.

In order to look more closely at aspects of interracial contact in school organizations, Table 3 groups the 194 schools by racial composition. Perhaps the most striking regularity that arises is in the gap between the percentage of nonwhites enrolled and the percentage of nonwhites in school organizations. Whereas nonwhites were slightly over-represented in organizations in the 51 most preponderantly white schools, they became increasingly underrepresented (as measured by that percentage point gap) in schools with higher nonwhite percentages. ${ }^{18}$ Also of interest is the calculated exposure rate in column E. This rate is calculated for each school as

$$
E=(1 / W) \sum_{i} W_{i}\left[N_{i} /\left(W_{i}+N_{i}\right)\right]
$$

where $\mathrm{W}_{\mathrm{i}}$ and $\mathrm{N}_{\mathrm{i}}$ are the number of whites and nonwhites, respectively, in organization $\mathrm{i}$ and $\mathrm{W}$ is the total number of whites in all organizations in the school. This rate is interpreted as the percentage nonwhite in the average white student's school organization. Two schools with the same overall racial mix, for example, would have different exposure rates if all the organizations in one school had the same racial makeup as the school while organizations in the other school differed in racial composition. In the extreme, a school whose organizations were entirely segregated by race would have exposure rates of zero, meaning that the average white student 
was in an organization with no nonwhites and the average nonwhite student was in an organization with no whites. If school groups in each school all had the same racial composition, this exposure rate would equal the percentage nonwhite in all organizations (shown in column C).

A convenient way to summarize the gap between the exposure rate and the overall nonwhite percentage is to define an index of segregation, based on the percentage divergence between this rate of exposure and the school's overall racial composition. This index is defined as

$$
\mathrm{S}=100(\mathrm{PCN}-\mathrm{E}) / \mathrm{PCN},
$$

where PCN is the overall proportion nonwhite in organizations. ${ }^{19}$ This measure ranges from zero, signifying racially balanced organizations, to 100, signifying that the school's organizations are completely segregated by race. Shown in column F of the table, the degree of segregation in organizations tends to be higher in schools with higher percentages of nonwhites. Overall, the actual degree of interracial exposure is some 26 percent less than it would be if all school organizations within each school had the same racial composition (0.211). Owing to the lower rate of participation in organizations among minority students, the gap between the degree of actual interracial contact in organizations and the rate that would exist if participation rates were equal and all organizations were racially balanced $(0.251)$ is 38 percent $(100(0.251$ $0.156) / 0.251))$.

Instead of percentages, one might like to know the number of students from another racial group any student member is exposed to in school organizations. Columns $\mathrm{G}$ and $\mathrm{H}$ of Table 3 give these averages. Based on the sample of yearbooks, white students who were members of 
school groups could expect on average to be in an organization with five nonwhites. By contrast, the average nonwhite member was in an organization with 21 whites. Not unexpectedly, the number of nonwhites for the average white increased with the school's overall nonwhite percentage, while the number of whites for the average nonwhite fell.

One other question of interest is whether students are in organizations in which they are significantly outnumbered by other racial groups. This situation would be uncommon if school organizations were characterized by "tipping points," thresholds beyond which members of one group will tend to abandon a neighborhood or organization. ${ }^{20}$ To see whether a phenomenon like this might be at work inside high schools, columns I and $\mathrm{J}$ of the table give the percentage of white and nonwhite members, respectively, who are in an organization in which a student's own racial group is 25 percent or less of the total membership. Column I shows quite clearly that this situation almost never occurs for white high school students. Only about 3 percent of the white members were in organizations where whites were a quarter or less of the group. For nonwhites, the experience was quite different: over half of the nonwhite members were in groups where they were outnumbered by whites by at least three-to-one. While these data do not prove there is a tipping point for whites in school organizations, they are consistent with the existence of one somewhere below 75 percent.

It is instructive to see how interracial contact differs among organizations of different types. Table 4 divides the 8,875 organizations in the sample schools into six categories for sports teams and three for other types of organizations. Sports teams accounted for roughly half of all organizations in the sample. The most striking (although perhaps not surprising) aspect of the table is the considerable divergence in racial composition across these types. Among the listed 
categories, the organizations with the highest percentages of white membership were the baseball and soccer teams, both over 90 percent white. At the other extreme were teams for two other sports, basketball and football, with slightly less than three quarters of their members being white. To see whether whites or nonwhites were systematically under-represented in organizations of various types, one needs to compare the racial composition of organizations with that of the schools with which each was affiliated. This comparison is presented in the table's next column, which shows a weighted mean for the difference between organization and school racial composition. These figures show that, on average, all but two of the nine types of organizations had a preponderance of whites. Those with the largest gaps were baseball, soccer, and publications. In two types of organizations, basketball and football, nonwhites were overrepresented.

A question of historical and policy importance to be posed in the current context is whether there is more or less interracial contact in the South, the region that until the 1960s maintained state-sanctioned segregation in public schools. One might reasonably conjecture that school organizations in the South would be more racially segregated than those elsewhere, perhaps as a manifestation of more virulent racial animosity or of informal pressures brought to bear by school authorities seeking to thwart desegregation efforts. In order to test this conjecture, regressions were run with data on organizations using as a dependent variables the percentage nonwhite in the organization and data on schools with a dependent variable the average exposure rate of white to nonwhite members. Equations (5.1) and (5.2) in Table 5 are based on the regressions for organizations, the second one adding indicators for the various types of school organizations listed in the previous table. To reflect the necessary dependence of organization 
racial composition on school racial composition, all of the right-hand-side variables are interacted with school racial composition, meaning that for an all-white school the regression will necessarily yield a prediction of all-white organizations. To allow the relationship to be nonlinear, school racial mix is entered as a cubic function. Equation (5.1) implies that, holding constant the school's racial composition, organizations in the South tended to have higher, not lower, percentages of nonwhites than those outside the South. No significant difference was found for private schools, however. ${ }^{21}$ Equation (5.2) adds dummy variables for eight of the nine organization types, each interacted with school racial composition. These variables reflect the differences in the propensity of whites and nonwhites to join various kinds of organizations, as revealed in Table 4 above. The addition of these variables has the effect of decreasing the regional effect, so that it is no longer significantly different from zero at the 95 percent level. Equation (5.3) takes on the question of regional difference by focusing on average interracial exposure in schools. It adds a measure of relative participation rate, the nonwhite representation gap used in previous tables (the difference between the percentage of nonwhites in organizations minus that in schools). The coefficient estimates in this regression reflect the importance of school racial composition and relative rates of participation. As in the previous two equations, percent nonwhite in the school has a positive but nonlinear effect. Exposure is also enhanced by greater participation by nonwhites. However, the estimated regional difference is quite small in relation to its standard error. In sum, none of the estimated regressions suggests that school organizations are any more a vehicle for segregation in the South as in the rest of the country. 


\section{Compared to What?}

Measured by the racial composition of their enrollments, public schools in the United States have become more integrated since the late 1960s. However, there is evidence that actual interracial contact is not as great as would be suggested by enrollments, due to academic tracking and self-segregation in friendship patterns. This paper examines interracial contact along another important but largely unexplored dimension: high school extracurricular organizations. The data are taken from a collection of 194 high school yearbooks. Tabulations based on these data reveal that sports teams and clubs tend to be racially imbalanced. The degree of interracial exposure in these school organizations is therefore typically less (averaging about 26 percent less) than it would have been had all the organizations in each school been racially balanced. If the comparison is to the racial composition of the schools themselves, the gap is even larger (38 percent). This increased gap is the result of the lower rate of participation by minority students in extracurricular groups. $^{22}$

These calculations arise from two features of participation in extracurricular activities. First, high school organizations tend not to be racially balanced. The result is that these organizations do not offer the same degree of interracial contact as they would if their memberships had reflected the enrollments of their respective schools. The second contributing factor is the higher rate of participation, noted elsewhere, of students from higher socioeconomic backgrounds and, correspondingly, of white students. In these extracurricular activities, one sees another example of how households can blunt the impact of public policies through private, often collective action. Although much less dramatic than moving their children to private schools, affluent parents are able to lessen the impact of desegregation by having their children participate 
more often than other students in extracurricular activities, by giving them opportunities to learn sports skills outside of school and being able to provide them with transportation to practices and after-school meetings.

Interpreting the evidence here on segregation in extracurricular activities has something of a half-full/half-empty character to it. If one takes as a point of comparison the racial composition that would exist if all organizations were to reflect the overall makeup of schools, then these figures suggest that the patterns of organization membership in these high schools has a sizable segregative effect, reducing the exposure that might otherwise have existed. This standard seems overly demanding, however, in part because academic tracking reduces interracial contact from the levels suggested by a school's overall racial composition. The scant information provided by Morgan and McPartland (1981) on the extent of actual interracial contact in high school classroom in 1976 suggests that tracking had the effect of reducing the interracial exposure rate by about 11 percent on average below what it would have been had classrooms been racially balanced. If one settles instead for the less stringent standard of the racial composition of those who actually participate, there is still imbalance which produces measured segregation.

Instead of using either of the racial-balance standard for judging the exposure rates for school organizations, it may be more realistic to take as the benchmark of comparison the extent of contact that would have existed if the only interracial contact outside of class arose from friendships. As noted above, interracial friendships appear to be quite uncommon. Using this as the standard of comparison, one would conclude that interracial contact has been enhanced rather than retarded as a result of extracurricular activities. Indeed, if the personal relationships that 
develop among members of clubs and teams are more significant for the formation of interracial tolerance and understanding than those in classrooms, the existence of these organizations may constitute an instrument with significant potential for more tolerant racial attitudes. 


\section{References}

Allport, Gordon W. 1954. The Nature of Prejudice. Cambridge, MA: Addison-Wesley.

Arrow, Kenneth J. 1998. "What Has Economics to Say About Racial Discrimination?"

Journal of Economic Perspectives 12 (Spring), 91-100.

Braddock, Jomills Henry II, Robert L. Crain, and James M. McPartland. 1984. “A Long-

Term View of School Desegregation: Some Recent Studies of Graduates as Adults," Phi Delta

Kappan 66 (December), 259-264.

Clotfelter, Charles T. 1976. “School Desegregation, 'Tipping,' and Private School

Enrollment," Journal of Human Resources 22 (Winter), 29-50.

Clotfelter, Charles T. 1978. “Alternative Measures of School Desegregation: A

Methodological Note." Land Economics 54 (Aug.):373-380.

Clotfelter, Charles T. 1999a. “Are Whites Still 'Fleeing'? Racial Patterns and Enrollment

Shifts in Urban Public Schools, 1987-1996," unpublished paper, Duke University.

Clotfelter, Charles T. 1999b. "Public School Segregation in Metropolitan Areas," Land

Economics 75 (November), 487-504.

Collins, Thomas W. 1978. "Reconstructing a High School Society after Court-Ordered

Desegregation," Anthropology and Education Quarterly 9 (Winter 1978), 248-257.

Ellison, Christopher G., and Daniel A. Powers. 1994. "The Contact Hypothesis and

Racial Attitudes among Black Americans." Social Science Quarterly 75 (June), 385-400.

Epstein, Joyce L. 1985. "After the Bus Arrives: Resegregation in Desegregated Schools," Journal of Social Issues 41 (No. 3), 23-43.

Gamoran, Adam. 1990. "Access to Excellence: Assignment to Honors English Classes in 
the Transition from Middle to High School," Educational Evaluation and Policy Analysis 14 (Fall 1992), 185-204.

Granovetter, Mark. 1986. "The Micro-Structure of School Desegregation,” in Jeffrey Prager, Douglas Longshore, and Melvin Seeman (eds.), School Desegregation Research: New Directions in Situational Analysis. New York: Plenum Press.

Hallinan, Maureen T. and Richard A. Williams. 1989. "Interracial Friendship Choices in Secondary Schools," American Sociological Review 54 (February), 67-78.

McNeal, Ralph B., Jr. 1998. "High School Extracurricular Activities: Closed Structures and Stratifying Patterns of Participation," Journal of Educational Research 91 (January/February), 183-191.

McNeal, Ralph B., Jr. 1999. "Participation in High School Extracurricular Activities: Investigating School Effects," Social Science Quarterly 80 (June), 291-309.

Moore, Kristin and Jennifer Ehrie. 1999. “Children’s Enrvironment and Behavior: Participation in Extracurricular Activities," Snapshots of America's Families, C-5 (Washington: Urban Institute).

Morgan, P.R. and James M. McPartland. 1981. "The Extent of Classroom Segregation within Desegregated Schools." Unpublished manuscript, Johns Hopkins University, Center for Social Organization of Schools. August.

Oakes, Jeannie. 1987. "Tracking in Secondary Schools: A Contextual Perspective," Educational Psychologist 22(No.2), 129-153.

Orfield, Gary. 1983. Public School Desegregation in the United States, 1968-1980. Washington, DC: Joint Center for Political Studies. 
Orfield, Gary, Mark D. Bachmeier, David R. James, and Tamela Eitle. 1997.

"Deepening Segregation in American Public Schools." Harvard Project on School

Desegregation, Unpublished Paper, Harvard University (April 5).

Orfield, Gary and Frank Monfort. 1992. Status of School Desegregation: The Next

Generation. Cambridge, MA: Metropolitan Opportunity Project, Harvard University. March.

Quiroz, Pamela Anne, Nilda Flores Gonzalez, and Kenneth A. Frank. 1996. "Carving a

Niche in the High School Social Structure: Formal and Informal Constraints on Participation in the Extra Curriculum," Research in Sociology of Education and Socialization 11 (1996), 93-120.

Rossell, Christine H. and David J. Armor. 1996. "The Effectiveness of School

Desegregation Plans, 1968-1991," American Politics Quarterly 24 (July), 267-302.

Schofield, Janet Ward. 1982. Black and White in School: Trust, Tension, or Tolerance New York: Praeger.

Schofield, Janet Ward. 1979. "The Impact of Positively Structured Contact on Intergroup Behavior: Does it Last Under Adverse Conditions? Social Psychology Quarterly 42, 280-284.

Schofield, Janet Ward. 1995. “Review of Research on School Desegregation's Impact on Elementary and Secondary School Students," in James A. Banks and Cherry A. McGee Banks (eds.), Handbook of Research on Multicultural Education . New York: MacMillan Publishing. U.S. Department of Education, National Center for Educational Statistics. 1999. Digest of Education Statistics 1998 (Washington, D.C.: Government Printing Office). 
Table 1

Means of Selected Variables, by Region and Type of School

Non-South South
Private Public Private Public

1 Number of Schools

19

90

$6 \quad 79$

194

Mean values (a)

2 School enrollment

3 Number of organizations

$\begin{array}{rrrrr}579 & 1,397 & 723 & 1,293 & 1,316 \\ 43 & 56 & 64 & 49 & 53\end{array}$

School racial composition (\%)

4 Black

10.2

6.5

8.8

8.8

3.4

31.8

17.8

5 Other nonwhite

19.0

15.3

9.4

5.5

7.3

6 Total nonwhite

(\%)

Organizations' racial composition (\%)

7 Black

8.9

5.7

12.8

37.3

25.1

8 Other nonwhite

9 Total nonwhite

7.9

16.7

6.7

3.0

$27.8 \quad 15.6$

$12.4-7.2$

4.0

5.5

$\begin{array}{lll}7.2 & 31.8 & 21.2\end{array}$

10 Under-representation of nonwhites in organizations (b)

$-2.3$

$-2.9$

$-5.6$

$-5.4$

$-4.0$

Note:

(a) Means are weighted by school enrollment.

(b) Difference between nonwhite percentage in organizations and the nonwhite percentage in school. 
Table 2

All-Nonwhite and All-White Organizations, Ten Selected High Schools

\begin{tabular}{|c|c|c|c|c|c|}
\hline School & & $\begin{array}{l}\text { School } \\
\text { type }\end{array}$ & $\begin{array}{l}\text { Percent } \\
\text { nonwhite } \\
\text { in school }\end{array}$ & All-nonwhite organizations & All-white organizations \\
\hline 1 & NY & Private & 20 & $\begin{array}{c}\text { Black Action Student Association } \\
\text { (BASA) } \\
\text { French Club } \\
\text { La Nacion Latina }\end{array}$ & $\begin{array}{c}\text { Fitness Club } \\
\text { Gaelic Club } \\
\text { Math Team } \\
\text { Varsity Volleyball } \\
\text { Varsity Basketball } \\
\text { Tennis } \\
\text { Golf }\end{array}$ \\
\hline 2 & MI & Public & 21 & (None) & $\begin{array}{c}\text { Baseball } \\
\text { Softball } \\
\text { Golf } \\
\text { Volleyball } \\
\text { JV Volleyball } \\
\text { Freshman Volleyball }\end{array}$ \\
\hline 3 & OK & Public & 24 & (None) & $\begin{array}{l}\text { Cheerleaders } \\
\text { Freshman } \\
\text { Cheerleaders } \\
\text { JV Baseball } \\
\text { Girls' Golf } \\
\text { Boys' Golf }\end{array}$ \\
\hline 4 & MA & Public & 37 & $\begin{array}{l}\text { Latin Club } \\
\text { Latino-American Club } \\
\text { Asian-American Club }\end{array}$ & $\begin{array}{c}\text { Yearbook } \\
\text { Girls State } \\
\text { Interact Club } \\
\text { Drama Club } \\
\text { Field Hockey } \\
\text { Indoor Cross Country }\end{array}$ \\
\hline 5 & SC & Public & 43 & Aframhis Club & $\begin{array}{l}\text { National Honor } \\
\text { Society } \\
\text { Interact Club } \\
\text { Fellowship of } \\
\text { Christian Athletes } \\
\text { Girls' Soccer }\end{array}$ \\
\hline 6 & $\mathrm{CA}$ & Public & 44 & $\begin{array}{c}\text { Drill Team } \\
\text { Movimiento Estudiantil Chicano De } \\
\text { Azlan (MECHA) } \\
\text { Black Student Union } \\
\text { Hispanic Youth Leadership }\end{array}$ & $\begin{array}{c}\text { Student Council } \\
\text { (Junior) } \\
\text { Student Council } \\
\text { (Freshman) } \\
\text { Women's Water Polo } \\
\text { German }\end{array}$ \\
\hline 7 & $\mathrm{TX}$ & Public & 49 & Multi-Cultural Association & Girls' Cross Country \\
\hline
\end{tabular}


Fellowship of

Christian Athletes

$8 \quad$ NC Public 49

JV Cheerleading Girls' Track

$9 \quad$ SC Public 54

Alpha Delta Rho
Chorus
Kappa Gamma Psi
Southeastern Consortium of Minority
Engineers (SCME)
Boys' Basketball

$10 \quad$ GA Public 68

Vocational Industrial Clubs of America
(VICA)
Vocational Opportunities Clubs of
America (VOCA)
Spanish Club
Girls' Track

JV Softball

Girls' Tennis JV Volleyball

Volleyball

Boys' Tennis

\section{Astronomy Club Golf \\ Boys' Tennis \\ Girls' Tennis}

\author{
Thespian Society \\ JV Cheerleading \\ Girls' Basketball \\ JV Girls' Basketball \\ Golf
}




\section{Table 3}

Interracial Contact by School Racial Composition

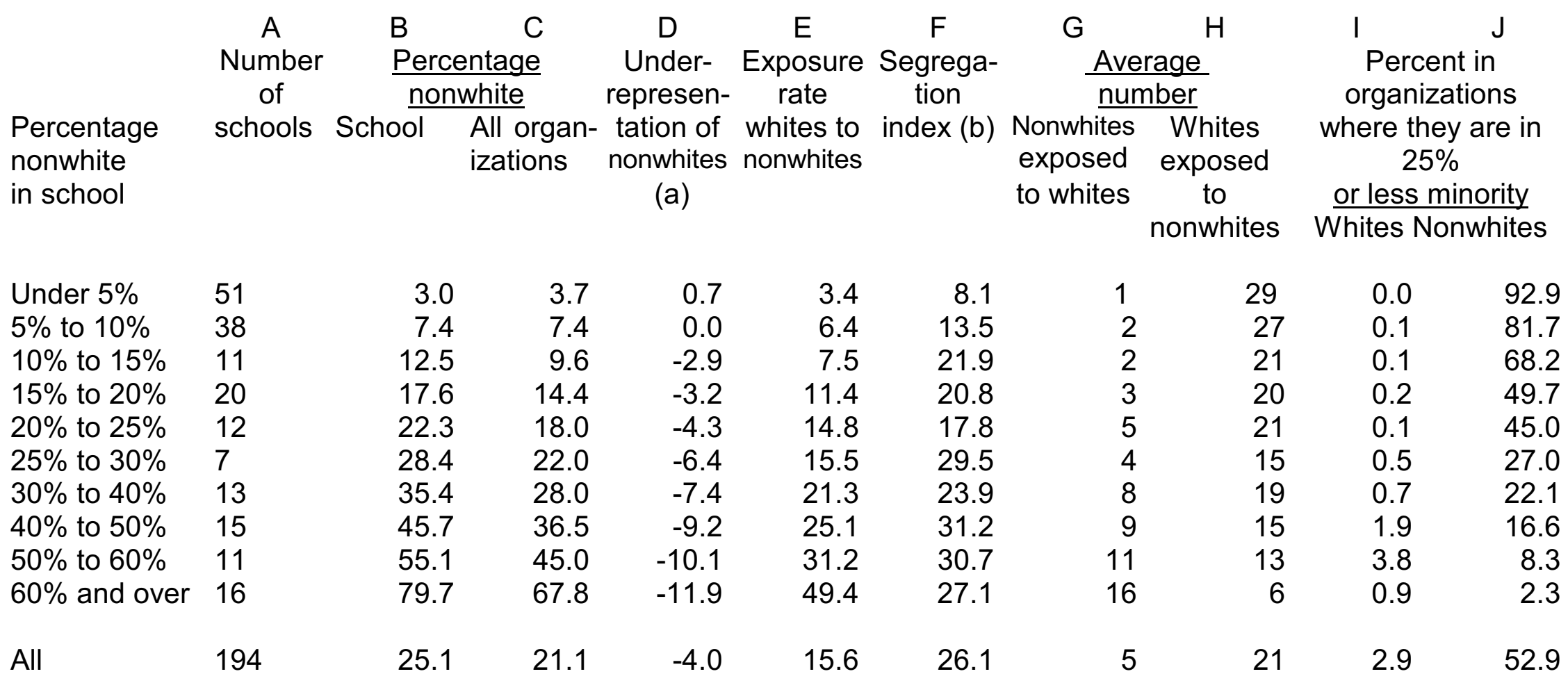

Note: Means weighted by school enrollment.

(a) Difference between nonwhite percentage in organizations and the nonwhite percentage in school.

(b) $100 *$ (percent nonwhite - exposure rate)/percent nonwhite. See text. 
Table 4

Summary Statistics by Type of Club, all High Schools

\begin{tabular}{|c|c|c|c|c|c|c|c|c|}
\hline \multirow[b]{3}{*}{$\begin{array}{l}\text { Type of } \\
\text { organization }\end{array}$} & & D & C & D & $\mathrm{E}$ & $\mathrm{F}$ & G & \multirow{3}{*}{$\begin{array}{c}\mathrm{H} \\
\text { Under } \\
\text { representation } \\
\text { of } \\
\text { nonwhites (a) }\end{array}$} \\
\hline & \multirow{2}{*}{$\begin{array}{l}\text { Number } \\
\text { of organiz- } \\
\text { ations }\end{array}$} & \multirow{2}{*}{\multicolumn{2}{|c|}{$\begin{array}{l}\text { Number of Average } \\
\text { schools with number of } \\
\text { at least one members }\end{array}$}} & \multicolumn{4}{|c|}{ Percentage of Members } & \\
\hline & & & & White & Black & $\begin{array}{c}\text { Other } \\
\text { nonwhite }\end{array}$ & $\begin{array}{c}\text { All } \\
\text { nonwhite }\end{array}$ & \\
\hline All organizations & 8,875 & 194 & 20 & 82.9 & 12.0 & 5.0 & 17.1 & -4.0 \\
\hline Sports teams & 4,444 & 194 & 17 & 84.5 & 11.7 & 3.8 & 15.5 & -4.3 \\
\hline Baseball & 551 & 156 & 15 & 91.5 & 5.9 & 2.6 & 8.5 & -15.1 \\
\hline Basketball & 762 & 18 & 12 & 73.9 & 23.6 & 2.5 & 26.1 & 7.6 \\
\hline Cheerleading & 434 & 173 & 12 & 86.3 & 10.6 & 3.0 & 13.7 & -7.0 \\
\hline Football & 297 & 165 & 36 & 73.2 & 24.5 & 2.3 & 26.8 & 3.0 \\
\hline Soccer & 467 & 159 & 19 & 91.3 & 3.2 & 5.5 & 8.7 & -11.5 \\
\hline Other sports & 1,933 & 192 & 17 & 87.3 & 8.0 & 4.7 & 12.7 & -6.7 \\
\hline $\begin{array}{l}\text { Other } \\
\text { organizations }\end{array}$ & 4,431 & 189 & 23 & 81.7 & 12.3 & 5.9 & 18.3 & -4.1 \\
\hline Perf & 844 & 167 & 29 & 84.9 & 11.0 & 4.1 & 15.1 & -5.8 \\
\hline Publications & 248 & 133 & 17 & 87.6 & 6.2 & 6.2 & 12.4 & -9.1 \\
\hline
\end{tabular}


Notes:

a) Nonwhite percentage in clubs minus nonwhite percentage in schools, weighted by school total enrollment. Source: Yearbook data and Common Core of Data; author's calculations. 
Table 5

Regressions Explaining Racial Composition in Organizations and Interracial Exposure

Equation

Unit of observation

Dependent variable
Organizations

Percent nonwhite in organization
$(5.2)$

Organizations

Percent nonwhite in organization
Schools (c)

Coefficient Std. Coefficient Std. Coefficient Std. error error error

Variable

$\begin{array}{lllllll}\text { Percent nonwhite } & \mathbf{0 . 9 3 8} & 0.030 & \mathbf{0 . 9 9 9} & 0.030 & \mathbf{1 . 0 7 4} & 0.057\end{array}$

Pct. NW squared
$-0.869$
0.100

$\mathbf{- 0 . 8 2 3} \quad 0.105$

$-1.345 \quad 0.162$

Pct. NW cubed

\subsection{0}

0.098

0.825

0.087

$1.185 \quad 0.124$

Pct.NW*SOUTH

\subsection{2}

0.016

0.029

0.015

$\begin{array}{ll}-0.009 & 0.013\end{array}$

Pct.NW*PRIVATE $\quad-0.048$

0.029

$-0.015$

0.028

$0.014 \quad 0.032$

NW representation (a)

$$
\mathbf{0 . 7 3 3} \quad 0.040
$$

Intercept

$-0.007 \quad 0.004$

Organization type dummy variable*Pct.NW

(b)

$\begin{array}{lrr}\text { Performing arts } & \mathbf{- 0 . 0 4 1} & 0.017 \\ \text { Publications } & \mathbf{- 0 . 2 7 1} & 0.040 \\ \text { Baseball } & \mathbf{- 0 . 4 0 9} & 0.027 \\ \text { Cheerleading } & \mathbf{- 0 . 1 3 5} & 0.034 \\ \text { Football } & \mathbf{0 . 2 3 4} & 0.022 \\ \text { Basketball } & \mathbf{0 . 3 6 5} & 0.025\end{array}$


Other sports

Soccer

R-square

$\mathrm{N}$ $-\mathbf{0 . 1 3 8} \quad 0.017$

$-0.372 \quad 0.031$

0.708

0.974

8,875

193

Note:

Regressions (5.1) and (5.2) are weighted by organization size; (5.3) is weighted by school enrollment.

Coefficients in bold are significant at the 95 percent level.

(a) Percentage nonwhite in all organizations minus percentage nonwhite in school.

(b) Excluded category is other organizations.

(c) One school with no whites excluded since exposure rate is undefined. 


\section{Notes}

1. In the current paper, the term "racial" is used as shorthand to refer to both racial and ethnic distinctions, white refers to non-Hispanic whites, and nonwhite refers to all others.

2. See, for example, Clotfelter (1999b).

3.For a study of the role of teams and clubs in a recently desegregated high school in Memphis during the 1970s, see Collins (1978).

4. The classic presentation of contact theory, and the conditions under which contact can lead to reduced prejudice, is given by Allport (1954). for a recent discussion of this issue, see Ellison and Powers (1994). According to their study, casual contact is less important than friendships in establishing the conditions for favorable effects on attitudes and behavior.

5. As Arrow (1998, p. 98) has noted, "social segregation can give rise to labor market segregation through network referrals." By the same token, increased interracial contact has the potential to exert the opposite effect See also Schofield (1995, p. 610) for a discussion of these effects.

6. For a description of recent trends, see Orfield et al. 1997. Greatly affecting these measured rates of integration in the public schools have been decisions by white families about where to move or whether to enroll their children in private schools. Whether these moves conform to the stereotype of "white flight" that occurs in direct response to changing racial compositions in the public schools or instead arise from more complicated decision-making based on a variety of factors, the effect of these moves has been to reduce the number of white students in many districts that enroll a significant number of minority students. For an analysis of white enrollment patterns in the face of public school desegregation, see Clotfelter (1999b).

7.Gamoran's (1992) study of placement in $9^{\text {th }}$ grade honors English classes in several midwestern school districts reveals significant under-representation of minority students, even when achievement test scores were controlled for. For a study of within-class grouping in elementary school, see Epstein (1985). For a summary of the arguments against tracking, including its racial aspects, see Oakes (1987), for example.

8. Using the same measure of segregation given in equation (2) of the current paper, based on black-white exposure indices (calculated as in equation (1) of the current paper), Morgan and McPartland find that the average index for their sample of high schools was 0.11 , implying that the interracial exposure rate in classrooms was 11 percent less than it would have been had classrooms been racially balanced within each school. They note that such segregation indices are equivalently based on white exposure to blacks or vice versa. The average divergence was 13 percent $(S=0.13)$ in high schools in the South. Among all high schools, the segregation rate was highest for those with 40 to 70 percent white enrollment (0.15) and lowest in schools with less 
than 10 or more than 90 percent white (0.06) (Morgan and McPartland 1981, Tables 3, 4.)

For a detailed study of interracial contact within a public middle school, see Schofield (1982).

In the absence of contemporary studies of intra-school racial segregation, one can add to this previous research little more than to speculate on how academic tracking might currently be affecting interracial contact. Consider, for example, a school with the same racial composition as the average of the 194 schools in the current sample. Ignoring other nonwhites, if black and white students in this hypothetical school were distributed across four academic tracks in the same proportions as they are actually distributed nationwide across four performance ranges in the National Assessment of Educational Progress (NAEP) test of reading proficiency for 17 yearolds (U.S. Department of Education 1998, Table 112, p. 130), the tracks would range from 8.7 percent black in the highest track to 45.4 percent in the lowest. Whereas blacks would comprise 19.2 percent of this hypothetical two-race school, the exposure rate of whites to blacks would be only 17.9 percent, implying a segregation index of $S=100(19.2-17.9) / 19.2=6.8$ percent. This gap is a bit smaller than, but still on the same order of magnitude as, the findings of Morgan and McPartland (1981) noted above.

9. See also Schofield (1979) for similar findings.

10. Quiroz, Gonzalez, and Frank (1996) argue that, because of school policies and other pressures, membership in high school organizations is neither open nor entirely voluntary. See also McNeal (1998, p. 184) for a discussion of this point.

11. For a detailed analysis of the role of organizations in the social network of one high school, see Quiroz, Gonzalez, and Frank (1996).

12. 25 , or 13 percent of the sample high schools were private, compared to 11 percent among all high schools in the U.S. (U.S. Department of Education 1999, Tables 5, 60; pp. 14, 71).

Regarding school size, as shown in Table 1, the average sizes of the private schools in the sample were 723 and 579 in and out of the South, respectively. For public schools, the comparable averages in the sample schools were 1,293 and 1,397. In the fall of 1995 the average private high school in the U.S. had 320 students and the average public high school had 595 (U.S. Department of Education 1999, Tables 3, 60; pp. 12, 71).

For purposes of this study, the South was defined as by Orfield and Monfort $(1992$, p. 2) as the eleven states of the Confederacy: Alabama, Arkansas, Florida, Georgia, Louisiana, Mississippi, North Carolina, South Carolina, Tennessee, Texas, and Virginia.

13. As a check of consistency across readers, selected schools were examined by two different readers and the results compared. Where one reader's tabulations differed from those produced by a benchmark reader, the former tabulations were redone.

14. Based on the random subsample of schools noted above, estimates using the $11^{\text {th }}$ grade were generally found to be quite close to the percentage of whites in the school, but tending to be somewhat higher. Estimates of total enrollment based on the $11^{\text {th }}$ grade averaged 10 percent too 
small, however.

15. If yearbooks systematically tend to picture whites at a higher rates than nonwhites, the calculations of nonwhite underrepresentation would be understated, as would be the actual gap in exposure. As noted above, the comparisons using the 10-school subsample show a slight tendency to include nonwhites less completely than whites in yearbook photos of individual students. If this tendency extended to pictures of school organizations, then the calculated rates of nonwhite participation would tend to overstate the true degree of underrepresentation.

16. In multivariate analysis, using two national surveys, McNeal (1998, p. 187; 1999, pp. 300301) found that participation rises with socioeconomic status and performance on standardized tests. Holding those and other factors constant, the partial effect on participation is actually positive for blacks for most types of activities. See also Moore and Ehrie (1999) for evidence from another national survey that participation in extracurricular activities by 12- to 17-year-olds rises with socioeconomic status.

17. Similar organizations included African Experience Club, African Heritage Club, AfroAmerican Club, and Black Action Student Association.

18. If, instead of measuring underrepresentation by the percentage point difference, it is measured by the proportional difference between the two rates, the degree of underrepresentation neither increases nor decreases systematically, remaining in most cases between 15 and 23 percent.

19. This ratio has been used to measure segregation in schools, for example, in Morgan and McPartland (1981) and Clotfelter (1999a, 1999b). For a discussion of it and its relationship to measures of exposure, see Clotfelter (1978).

It is useful to note that the value of $S$ is invariant with respect to which of two groups is used as the basis for calculating the exposure rate. That is, $\mathrm{S}$ can be calculated using the exposure of nonwhites to whites, where $\mathrm{W}$, the overall percentage of students who are white, is the maximum for this exposure rate: $\mathrm{S}=\left(\mathrm{W}-\mathrm{E}_{\mathrm{NW}}\right) / \mathrm{W}$.

20. For a discussion of tipping points in the context of school desegregation, see Clotfelter (1976).

21. Similar results were obtained from a model, estimated for a smaller sample for whose schools data were available, that included the median income of the ZIP code where the school was located.

22. Another qualification to the measures of segregation used in the current paper is the argument that the correct benchmark of comparison ought not to be an exactly racially balanced composition, but rather the exposure rate that would arise if membership in organizations were random.. Owing to the small size of these school organizations, the laws of chance would determine that their racial compositions would often deviate somewhat from the racial composition of all members of organizations or the school, depending on which standard was being used. Using the binomial distribution, sample calculations were made of expected 
exposure rates under the assumption of random assignment. When calculated, these rates turned out to be quite close to the racial balance rates, so the latter standard was retained, as is conventional in studies of segregation. 